\title{
APPARENT ADOPTION OF ORPHANED COUGARS (PUMA CONCOLOR) IN NORTHWESTERN WYOMING
}

\author{
Travis D. Bartnick ${ }^{1,3}$, Marilyn Cuthill1ㄹ, Derek Craighead ${ }^{1}$, and Howard B. Quigley ${ }^{1,2}$
}

\begin{abstract}
Cougars (Puma concolor) are widely distributed throughout the western portion of North America and are generally described as solitary carnivores. Most cougar social interactions have been described as instances of parental care, intraspecific strife, or breeding. We report an apparent case of an adoption of orphaned juveniles in a wild cougar population. We used radiotelemetry and direct visual observations to document an adult female, her 3 dependent offspring, and 2 orphaned juvenile males physically interacting, sharing bed sites, and sharing kills in the late winter of $2007 / 2008$. We consider the potential benefits and/or negative effects of these social interactions, and the role that relatedness and/or familiarity may play in the motivation for developing such associations.
\end{abstract}

Resumen.-Los pumas (Puma concolor) se encuentran en toda la zona occidental de Norteamérica y son descritos como carnívoros solitarios. La mayor parte de las interacciones sociales de los pumas son casos de cuidado parental, crianza o conflictos intraespecíficos. Reportamos un aparente caso de adopción de crías juveniles huérfanas en una población de pumas salvajes. Utilizamos radiotelemetría y observación directa para documentar la conducta de una hembra adulta, sus tres crías dependientes y dos crías machos juveniles huérfanos que interactuaban físicamente, compartían las áreas de descanso y las presas, a finales del invierno de los años 2007/2008. Evaluamos los posibles beneficios $\mathrm{y} / \mathrm{o}$ efectos negativos de estas interacciones sociales y la influencia que este parentesco y/o familiaridad puede tener para desarrollar dichas asociaciones.

Most large, free-ranging carnivores are difficult to observe for long periods in the wild (Bekoff et al. 1984, Gese 2001), and despite several long-term studies of cougars (Puma concolor) in North America over the past few decades, few visual observations of cougar social behavior and other intraspecific interactions over an extended period have been documented or published. This dearth of observations may be partially attributed to characteristics of suitable cougar habitat (e.g., vast, continuous, and undeveloped), as well as the sparse distribution and elusive behavior of cougars. Of the studies that document social interactions, most involve cases of intraspecific strife and/or breeding behavior (Hornocker 1969, 1970, Seidensticker et al. 1973, Pierce et al. 1998, Logan and Sweanor 2001). Logan and Sweanor's (2001) long-term study of cougars in the desert Southwest of the United States documented that only $5.1 \%$ of observations involved a situation where independent cougars associated with other cougars. Of the male-female associations, $75.3 \%$ occurred while the female was in estrous, and of the male-male associations, nearly one-third resulted in death due to intraspecific strife. Logan and Sweanor (2001) concluded that intraspecific interactions were risky and that avoidance was the best survival tactic.

Kitten orphanage is common in hunted cougar populations (Logan and Sweanor 2001, Stoner et al. 2006, WGFD 2006). However, tracking and monitoring the minimum age at which orphaned cougars are likely to survive on their own is difficult. Recent observations suggest that cougars up to 12 months old may not have developed the skills necessary to effectively hunt and take large prey (Elbroch and Quigley 2013). Additionally, there are no published records of orphaned cougars engaging in behaviors characteristic of adoption, such as interacting and sharing multiple kills with a nonmaternal adult for an extended period. Adoption is an extended form of alloparenting (Riedman 1982) typified by care for conspecific young by individuals other than one or both of the genetic parents (Wilson 1975). Although various forms of alloparenting have been documented in over 120 species of mammals, adoptions are rare outside of an experimental or captive setting (Riedman

\footnotetext{
${ }^{1}$ Craighead Beringia South, Box 147, Kelly, WY 83011

${ }^{2}$ Panthera, Box 11363, Bozeman, MT 59719.

3E-mail: travisdbartnick@vahoo.com
} 


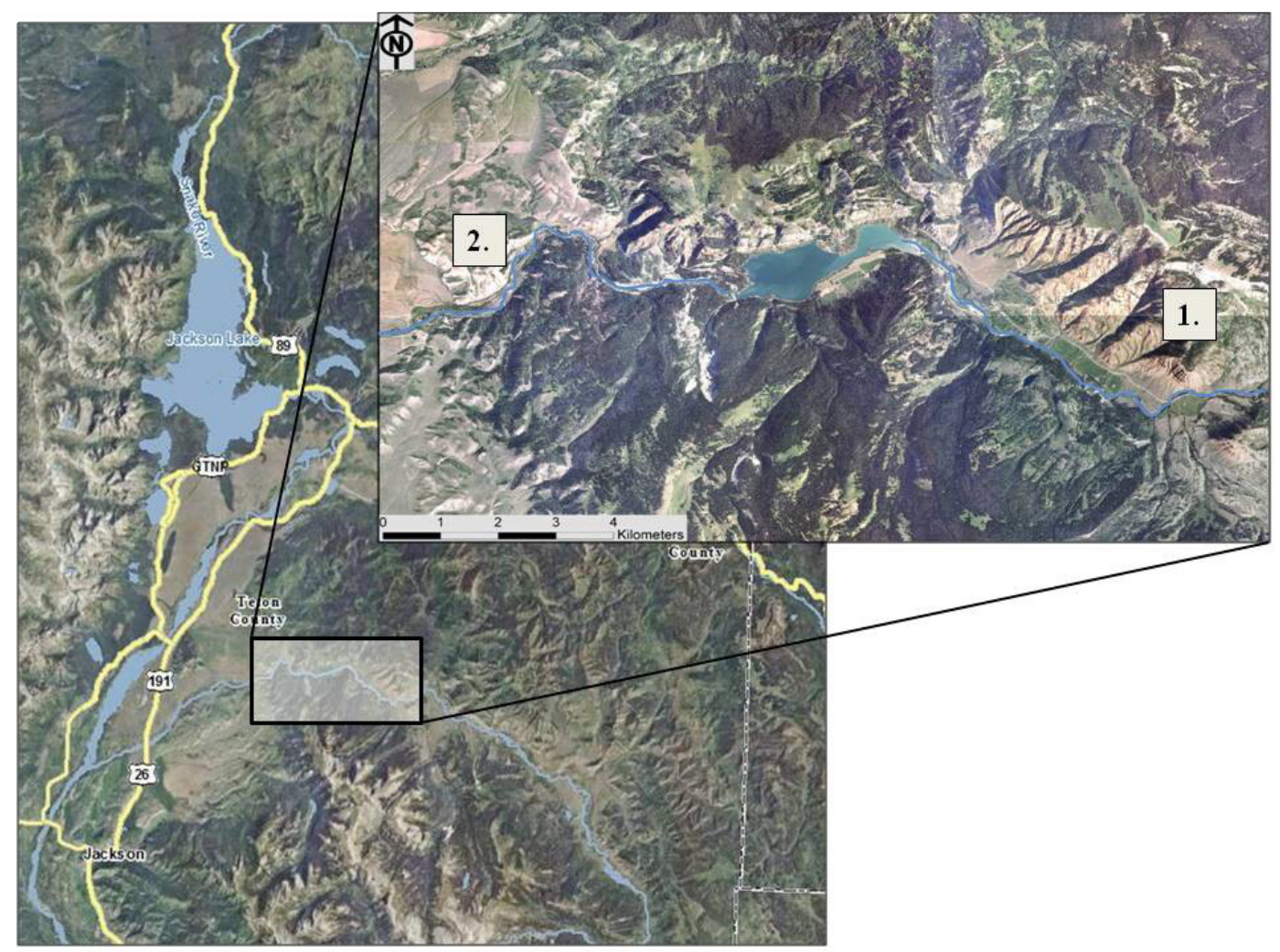

Fig. 1. Compressed National Agriculture Imagery Program (NAIP) true-color digital orthoquadrangle of the Teton Cougar Project study area in northwestern Wyoming, USA: 1, the location where we first located the orphaned cougars with the F27 family group in the Red Hills; 2, The Gros Ventre River Canyon area where we observed the 2 orphaned males interacting with the F27 family group. Imagery accessed at http://www.uwyo.edu/wygisc on 4 September 2013.

1982). Adoption is typically more common in social felids, such as cheetahs (Acinonyx jubatus; Caro 1994), and lions (Panthera leo; Schaller 1972), and only one case of adoption by a solitary felid has been documented (i.e., leopard, Panthera pardus-Balme et al. 2012). We present, to our knowledge, the first apparent adoption of orphaned cougars documented in peer-reviewed literature.

The Teton Cougar Project was initiated in 2000 and has continued through 2013 as a broad ecological study of the cougar population within the southern Greater Yellowstone Ecosystem in northwestern Wyoming, USA (Elbroch et al. 2012). We implemented the use of VHF and GPS radio-collar technology to conduct intensive monitoring of individuals within the local study population. We used VHF collars during the earlier years of the study, and after 2006 we attempted to affix GPS collars to all resident adult cougars within the study area. We tracked and visually observed members of 2 different family groups in the Gros Ventre river system, approximately 26 $\mathrm{km}$ northeast of Jackson, Wyoming.

On 11 December 2007, an approximately 11-year-old female (designated F1) fitted with a VHF radio-collar was killed in a legal hunt. At that time, F1 was accompanied by her 3 offspring, approximately 15 months old, including 2 males (designated M38 and M21) and one female (F69). We had previously fitted each of the offspring with VHF radiocollars. Daily radio-tracking and investigations of potential kill sites provided no evidence indicating that the offspring were making kills independent of their mother. From 11 December 2007 through 21 December 2007, the 3 orphans remained confined to a forested bench above an area locally referred to as the Red Hills, within $1 \mathrm{~km}$ of where their mother, F1, had been killed. During this time, we 
attempted to obtain visual observations of the orphaned offspring, but failed due to accessibility difficulties and restrictions. Our project protocol limited us from approaching study animals in a manner that could negatively influence their natural behavior. On 21 December 2007 , we used radiotelemetry methods to locate a 9-year-old female (F27), her three 6month-old kittens (F61, F66, and U65), and the 3 orphans in the same location (Fig. 1). On 22 December 2007, estimated radiotelemetry locations indicated that the F27 family group had departed from the location of the orphans.

From 23 December 2007 to 9 January 2008, the 3 orphans traveled the Gros Ventre River drainage to a location approximately $10 \mathrm{~km}$ from the initial site where we had previously located them with the F27 family group. We later searched the area the orphans had previously occupied and found no evidence of a kill. On 10 January 2008, F69 separated from her 2 male siblings and began killing prey independently.

On 15 January 2008, we located the orphans M38 and M21 with the F27 family group near the mouth of the Gros Ventre River Canyon, approximately $14 \mathrm{~km}$ from the initial documented encounter site (Fig. 1). From 15 January 2008 through 6 April 2008, we located one or both of the orphaned males in proximity to various members of the F27 family group on several occasions. During these occasions, the orphans remained in proximity for periods up to 7 days. Additionally, radiotelemetry indicated that F27 left the orphaned males alone with her 3 dependent kittens on at least one occasion, and we presumed that F27 was hunting during this time. Throughout this apparent adoption period, we made direct visual observations and/or performed post hoc investigations at predation sites. These observations provided evidence that all members of F27's family group shared prey carcasses and bedded together at or near the predation sites with M38 and M21.

On 3 separate occasions, we made direct visual observations of one or both of the 2 orphans interacting with F27 and/or her 3 dependent kittens. We observed our first instance of nonfamilial cougar social interactions on 31 March 2008 between 15:30 and 16:50 MST. We used radiotelemetry, binoculars, and a spotting scope to identify individual cougars from an adjacent ridge approximately $275 \mathrm{~m}$ to the east of a previously observed kill site. We first observed orphan M38 and kitten U65 for 30 min while they bedded under a spruce tree (Picea spp.) in a mixed timber river bottom. Kitten U65 was $1 \mathrm{~m}$ ventral to M38's position and appeared to be attempting to engage M38 in playful activity. Subsequently, we observed F27, F61, and M21 approaching a mule deer (Odocoileus hemionus) carcass in the open, approximately $150 \mathrm{~m}$ upslope from M38 and U65 (16:05 MST). F61 stopped and began to feed on the carcass as M21 and F27 walked $3 \mathrm{~m}$ upslope and laid down with their backs to each other. Approximately 5 min later, M21 walked downslope, and began feeding on the mule deer carcass (16:15 MST). Kitten F61 remained feeding at the carcass as M21 approached. After F61 and M21 had been feeding for 2 min, F61 returned to her mother, F27, and they engaged in grooming behavior. Soon after, kitten F61 walked out of our line of sight. Orphan M21 continued feeding on the carcass for the next 20 min while F27 continued to lie still (16:50 MST). Between 1 April 2008 and 2 April 2008, orphan M38 dispersed from the group and did not return.

We observed the second instance of nonfamilial cougar interactions on 5 April 2008 between 13:20 and 17:20 MST. At 13:20 MST, radiotelemetry indicated M21 and U65 were located in the timbered river bottom and out of sight from our vantage point. At 15:55 MST, M21 and U65 joined F27 and her 2 other kittens at a kill site. As the 5 cougars made first contact, they strode in a circular motion, and the 3 kittens moved into and out of our view. Subsequently, F27 and M21 walked toward each other and rubbed their faces and necks together. F27 then led the 4 cougars single file into the timbered shade and out of our line of sight.

We observed the third instance of nonfamilial cougar social interactions on 6 April 2008 between 14:50 and 20:00 MST. We first observed F27 and M21 bedded down in a cliff band about $50 \mathrm{~m}$ upslope from the bottom of the Gros Ventre River canyon. F27 and M21 engaged in behaviors such as exposing their teeth at each other, false biting, and mutual grooming. M21 also stretched his rear leg on top of F27's lower back and tail. As dusk approached, F27 and M21 moved toward the bottom of the cliff, and 2 of the 3 kittens appeared from the timber and joined the 
group while the third kitten meandered across the hillside. All cougars then moved out of sight and into the forested river bottom. On 7 April 2008, telemetry locations indicated that M21 was approximately $1 \mathrm{~km}$ from the F27 family group. Subsequent telemetry locations indicated that M21 had dispersed and had begun making kills independently.

These observations represent previously undocumented social behavior in cougars and the first known documented apparent adoption of orphaned littermates by an adult female with young dependent kittens. It was evident that after the harvest of their mother, the orphaned males remained dependent on another adult before they reached sufficient independence to effectively take large prey. It was also apparent that F27 tolerated the presence of the orphans and would leave them with her 3 young offspring. Although the juvenile males did occasionally venture off on their own for several days at a time during the apparent adoption period, they never remained in one location long enough to indicate that they were independently killing and feeding on large prey.

Philopatry is common among female cougars (Murphy 1998, Pierce et al. 2000, Sweanor et al. 2000) and can often lead to establishment of matrilines (Sweanor et al. 2000). Female cougars typically disperse shorter distances than males, even to areas adjacent to their mother (Ross and Jalkotzy 1992, Logan and Sweanor 2001). We do not know the relationship between F1 and F27, but given the matrilineal structure of cougars and the facts that F1 was 2 years older than F27 and that they had overlapping home ranges, it is probable that these individuals were closely related (e.g., mother-daughter, aunt-niece, or halfsiblings). Current researchers on the Teton Cougar Project were in the process of analyzing genetic relatedness among the individuals at the time this manuscript was submitted for publication (H.B. Quigley, personal communication). Additionally, it is possible that given the proximity of $\mathrm{F} 1$ and $\mathrm{F} 27$ 's ranges, the 2 family groups may have had prior interactions. Short-term observations of large, multifamily groups of cougars have been previously reported (see Tischendorf et al. 1995).

Another possible explanation for these behaviors is that the 2 orphaned males, being large and close to dispersal age, may have benefitted F27 by allowing her to leave her young kittens with them while she hunted. Had the orphans been female (potentially philopatric) or much younger, the duration of the apparent adoption would likely have been longer and more energetically costly to F27. The time of year that these events occurred may have influenced the outcome of the apparent adoption as well. Late winter through early spring is when ungulate prey are aggregated and typically in their weakest, most vulnerable condition. Had these events occurred in late summer or fall when ungulates are in peak condition, the apparent adoption may have resulted in higher energetic costs to F27. Additionally, the level of defense of the group from other large carnivores in the area (e.g., wolves [Canis lupus], adult male cougars) may have been superior with the presence of the larger juvenile males. The apparent adoption may have provided some inclusive fitness benefits if, for example, F27 were closely related to the orphaned males and the cost of provisioning them for an additional 3-4 months was outweighed by the benefit of (potential) protection for her own kittens from the threat posed by wolves and adult male cougars.

We do not know how common alloparenting or adoption occurs in solitary felid species such as cougars. The social behaviors we observed may have previously gone undetected, or perhaps this particular case was an anomaly. However, considering that cougar social organization is structured around matrilines and that kitten orphanage is a common artifact of exploitation (Barnhurst and Lindzey 1989, Stoner et al. 2006, WGFD 2006), the potential for adoption may be high in hunted populations. More instances of family groups interacting at kill sites have been observed since this adoption (Elbroch and Quigley 2013, H.B. Quigley unpublished data). Additionally, recent cougar studies have implemented an increased use of GPS collars (Knopff et al. 2010, Ruth et al. 2010, Bartnick et al. 2013) and camera-trapping methods (Pierce et al. 1998, Harmsen et al. 2010). These tools have provided the scientific community with new and valuable insights into cougar behavior and ecology. Further research and continued use of new and developing technology may reveal how often cougars exhibit such social behaviors. 
We thank all volunteers and field technicians who assisted on the project. Thanks to M. Elbroch for comments on an earlier version of this manuscript. We also thank S. Cain of Grand Teton National Park; D. Moody, T. Fuchs, and D. Thompson of the Wyoming Game and Fish Department; K. Murphy and D. Deiter of the Bridger-Teton National Forest; the Richard King Mellon Foundation; the Charles Engelhard Foundation; the Laura Moore Cunningham Foundation; the Summerlee Foundation; the Tim and Karen Hixon Foundation; the National Geographic Society; the Norcross Wildlife Foundation, Inc.; Mr. L. Westbrook; S. and L. Robertson; the Eugene V. \& Clare E. Thaw Charitable Trust; the Connemara Fund; Mr. and Mrs. G. Ordway; the Oregon Zoo Foundation, and the Cougar Fund.

\section{Literature Cited}

Balme, G., L. Hunter, and N. De Woronin Britz. 2012. A case of offspring adoption in leopards, Panthera pardus. South African Journal of Wildlife Research 42:63-66.

Barnhurst, D., and F.G. Lindzey. 1989. Detecting female mountain lions with kittens. Northwest Science 63:35-37.

Bartnick, T.D., T.R. Van Deelen, H. Quigley, and D. Craighead. 2013. Variation in cougar (Puma concolor) predation habits during wolf (Canis lupus) recovery in the southern Greater Yellowstone Ecosystem. Canadian Journal of Zoology 91:82-93.

Bekoff, M., T.J. Daniels, and J.L. GitTleman. 1984. Life history patterns and the comparative social ecology of carnivores. Annual Review of Ecology, Evolution, and Systematics 15:191-232.

Caro, T.M. 1994. Cheetahs of the Serengeti plains: group living in an asocial species. University of Chicago Press, Chicago, IL.

Elbroch, L.M., AND H. Quigley. 2013. Observations of wild cougar (Puma concolor) kittens with live prey: implications for learning and survival. Canadian Field-Naturalist 126:333-335.

Elbroch, L.M., H. Quigley., and D. Craighead. 2012. The Teton Cougar Project: cougar ecology and monitoring in the southern Greater Yellowstone Ecosystem. Progress report prepared for Craighead Beringia South, Kelly, WY, and Panthera, New York, NY.

GESE, E.M. 2001. Monitoring of terrestrial carnivore populations. Pages 372-396 in J.L. Gittleman, S.M. Funk, D.W. MacDonald, and R.K. Wayne, editors, Carnivore conservation. Cambridge University Press and Zoological Society of London, Cambridge.

Harmsen, B.J., R.J., Foster, S.M. Gutierrez, S.Y. Marin, AND C.P. Doncaster. 2010. Scrape-marking behavior of jaguars (Panthera onca) and pumas (Puma concolor). Journal of Mammalogy 91:1225-1234.
Hornocker, M.G. 1969. Winter territoriality in mountain lions. Journal of Wildlife Management 33:457-464. 1970. An analysis of mountain lion predation upon mule deer and elk in the Idaho Primitive Area. Wildlife Monographs 21:3-39.

KnopfF, K.H., A.A. KnopfF, A. Kortello, and M.S. Boyce. 2010. Cougar kill rate and prey composition in a multiprey system. Journal of Wildlife Management 74:1435-1447.

Logan, K.A., AND L.L. SwEanor. 2001. Desert puma: evolutionary ecology and conservation of an enduring carnivore. Island Press, Washington, DC.

Murphy, K.M. 1998. The ecology of the cougar (Puma concolor) in the northern Yellowstone ecosystem: interactions with prey, bears, and humans. Doctoral dissertation, University of Idaho, Moscow, ID.

Pierce, B.M., V.C. Bleich, and R.T. Bowyer. 2000. Social organization of mountain lions: does a land tenure system regulate population size? Ecology 81: $1533-1543$.

Pierce, B.M., V.C. Bleich, C.B. Chetkiewicz, and J.D. Wehausen. 1998. Timing of feeding bouts of mountain lions. Journal of Mammalogy 79:222-226.

Riedman, M.L. 1982. The evolution of alloparental care and adoption in mammals and birds. Quarterly Review of Biology 57:405-435.

Ross, I.P., AND M.G. JALKOTZY. 1992. Characteristics of a hunted population of cougars in southwestern Alberta. Journal of Wildlife Management 56:417-426.

Ruth, T.K., P.C. BuotTe, And H. Quigley. 2010. Comparing ground telemetry and global positioning system methods to determine cougar kill rates. Journal of Wildlife Management 74:1122-1133.

Schaller, G.B. 1972. The Serengeti lion: a study of predator-prey relations. University of Chicago Press, Chicago, IL.

Seidensticker, J.C., M.G. Hornocker, W.V. Wiles, And J.P. Messick. 1973. Mountain lion social organization in the Idaho Primitive Area. Wildlife Monographs 35:3-60.

Stoner, D.C., M.L. Wolfe, and D.M. Choate. 2006. Cougar exploitation levels in Utah: implications for demographic structure, population recovery, and metapopulation dynamics. Journal of Wildlife Management 70:1588-1600.

Sweanor, L.L., K.A. Logan, and M.G. Hornocker. 2000. Cougar dispersal patterns, metapopulation dynamics, and conservation. Conservation Biology 14 : 798-808.

TischendorF, J.W., D.J. ScotT, S.D. ScotT, AND B. HeICHER. 1995. A sighting of a large group of pumas (Puma concolor). Southwestern Naturalist 40: 226-227.

Wilson, E.O. 1975. Sociobiology. Harvard University Press, Cambridge, MA.

[WGFD] Wyoming Game and Fish Department. 2006. Mountain lion management plan. Lander, WY.

Received 3 April 2013

Accepted 20 December 2013 